Bulletin of the Natural History Museum, 2017, 10: 7-28.

Received 11 Jan 2017; Accepted 13 Aug 2017.

doi: $10.5937 / \mathrm{bnhmb} 1710007 \mathrm{M}$

UDC: $502.15 / .17(497.11)$

Original scientific paper

\title{
ACTIVITIES ON THE ESTABLISHMENT OF DJERDAP GEOPARK (SERBIA) AND CANDIDATURE OF THE AREA TO THE UNESCO GLOBAL GEOPARK NETWORK
}

\author{
ALEKSANDRA MARAN STEVANOVIĆ \\ Natural History Museum, Njegoševa 51, 11000 Belgrade, Serbia, e-mail: \\ amaran@nhmbeo.rs
}

Among several prospective regions in Serbia, the Djerdap area has been chosen for the nomination in the UNESCO Global Geoparks Network due to many reasons: its strategic position, diverse natural and cultural resources, a long tourism tradition and an aspiration of local residents to be involved in planned promotional activities. Djerdap geopark is positioned in the northeastern part of Serbia, covering a territory of 1330 square kilometers and includes the area of Djerdap National Park, but exceeds it spatially for additional 692 square kilometres. Main initiatives and actions on the establishing Djerdap geopark are presented together with the most valuable natural and cultural-historical aspects as well as future priority tasks.

Key words: Djerdap area, Serbia, UNESCO Global Geoparks Network, natural and cultural characteristics, human resources, initial activities and actions.

\section{INTRODUCTION}

Geopark is clearly defined territory in which main activities are oriented to exploring, protecting and promoting not only internationally important geoheritage but also other valuable natural and cultural resources 
in the area through tourism development, aiming to stimulate and engage the local communities, enhance their socio-economic status, advance geoconservation and, create a balance between the economic growth and environmental protection (Mc Keever \& Zouros 2005, Maran 2010). A geopark is managed by an appropriate defined structure, organized according to the national legislation, able to enforce the protection, enhancement and sustainable development policies within its territory. Activities in geopark are primarily financed through local and national sources, supported by regional development funds of the European Union.

Establishment of geoparks, the European Geoparks Network (EGN) and the UNESCO Global Geoparks Network (UNESCO GGN) was one of the most important international geoconservation initiatives. In the initial European Geoparks Network, founded in 2000, four territories of similar natural and socio-economic characteristics have been selected: La Reserve geologique de Haute-Provence (France), Lesvos Petrified Forest (Greece), Maestrazgo Cultural Park (Spain) and Volcanic Eifel Nature Park (Germany). The European Geoparks Network currently comprises 70 regions in 23 countries whereas the Global Geoparks Network, established in 2004, encompasses 127 areas worldwide, including European geoparks.

Members of the Working Group for the establishment of National Geoparks in Serbia, formed in early 2014 under the umbrella of the Ministry of Agriculture and Environmental Protection, have analyzed the natural, cultural, scientific, educational and tourism potentials of certain areas in Serbia. Based on the evaluation of several prospective regions, it was decided to choose the Djerdap area for a candidacy to the UNESCO Global Geoparks Network due to its geographic position, valuable natural

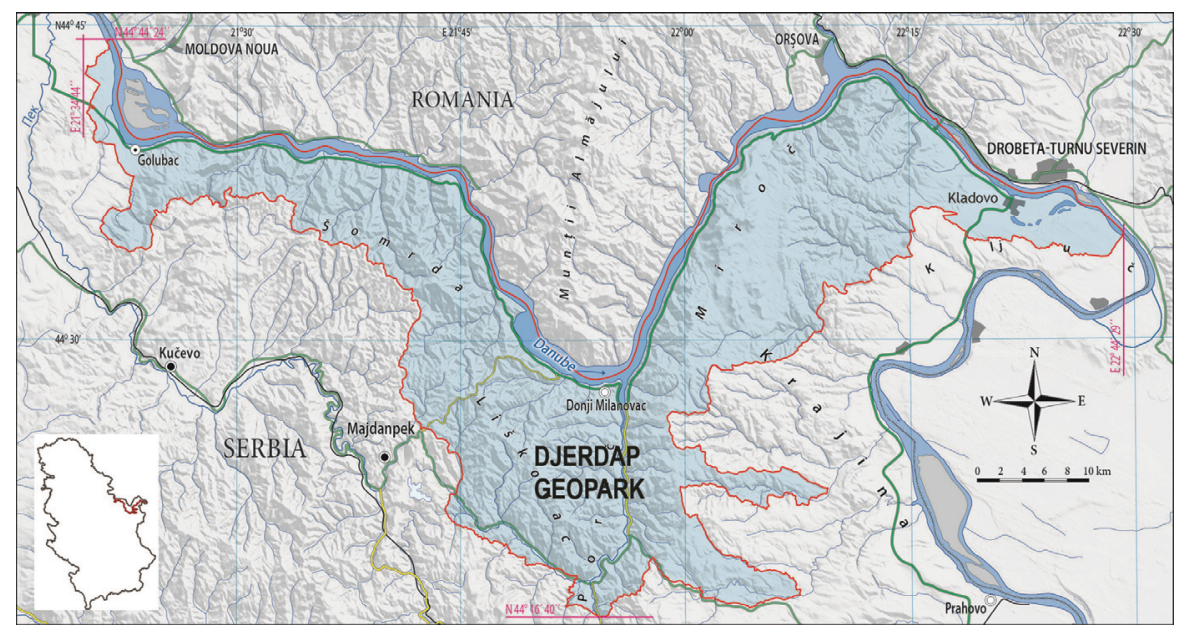

Fig. 1. - Position of Djerdap Geopark area (Application dossier section A, after M. Milivojević, modified) 
and cultural resources, a long tourist tradition and enhanced employment opportunities as well as real economic benefit for the people who live there primarily through the development of geotourism.

The Djerdap aspiring geopark is located in the northeastern part of Serbia, along the border with the Republic of Romania. It covers spatially an area of 1330 square kilometers and includes the area of the Djerdap National Park, but exceeds its territory for additional 692 square kilometers (Figure 1).

The Djerdap National Park is one of the five national parks in the Republic of Serbia. It extends over the territory of 638 square kilometers and comprises riparian part of the Djerdap gorge in the middle course of the Danube River and its hinterland - parts of the massifs Kučaj and Miroč. The area of the NP Djerdap is divided into three different protection zones. The first zone (5.121 hectares or eight percent) refers to the strict protection of natural and cultural heritage. The second one covers the area (13.715 hectares or 21.5 percent) surrounding the first zone and applies to the special nature values (specific ecosystems, geological and geomorphological sites) and natural areas around cultural monuments. The third zone (44.950 hectares or 70.5 percent) applies to the territory outside the borders of the first and second protection zones and permits activities related to: tourism, sports, recreation, forestry, water use, potential exploitation of mineral resources, urban construction and development.

Although the NP Djerdap was established in 1974, the Public Enterprise "National Park Djerdap" (PE "NP Djerdap"), was officially founded almost twenty years later, after the enact of Law on National Parks in 1993. The PE "NP Djerdap" is in charge for the realization of management concept, based on: preservation and sustainable use of natural and cultural heritage, implementation of the prescribed protection regimes, supervision of protective conditions and measures, prevention of all activities and actions that are opposed to national, regional and local laws as well as those that represent threats to protected area. The PE "NP Djerdap" is divided into three sections: Inspection service, Department of protection and development and Department of joint affairs. The Inspection service is engaged in surveillance operations and functions independently of the other two departments. As a core of the enterprise, the Department of protection and development carries out all activities related to the protection and development of natural resources, including forest management, and the protection and improvement of breeding fish fauna. The Department of joint affairs is in charge for legal and administrative affairs, finances and marketing. 
Members of the Working Team for the establishing Djerdap Geopark ${ }^{1}$, founded officially in 2014 by the Ministry of Agriculture and Environmental Protection (coordinator M. Mladenović, Group for protected areas within the Ministry) made an agreement that the organization of future geopark will rely upon the existing management structure of the Djerdap National Park with continual assistance of newly established Expert and Technical boards. The Expert board consists of the representatives of scientific, educational and professional institutions who deal with all subjects regarding sustainable operation and implementation of actions for development of the proposed Geopark and also provide scientific, educational and professional support. Members of the Technical board are representatives of related governmental bodies, local authorities, local communities, local tourist organizations and local private sector. Their participation in the geopark activities is mainly focused on socio-economic recovery and stimulation of the existing economic and tourist potentials.

\section{MAIN CHARACTERISTICS OF THE DJERDAP AREA}

Djerdap Gorge is the most prominent natural phenomenon in the area (Figure 2). On its 117 kilometers long path from Golubac to Kladovo, the Danube River cuts into the perimeter of Southern Carpathians and connects the Pannonian Basin on the west and Dacian Basin on the east (Maran Stevanović \& Ćalić 2017). Considered to be the longest incising composite gorge in Europe, it encompasses four smaller gorges (Golubac or Upper Gorge, Gospodjin Vir, Kazan and Sip) and three valleys among them (next to the cities Liubcova, Donji Milanovac and Orşova). This area hosts more than 50 different types of forest and bush communities that inhabits various and rich fauna. Due to its geographical position, available natural resources and mild climate, the area has been a dwelling place for several civilizations, from the Mesolithic time to the present.

The Gorge is one of the best studied areas of the Balkan Peninsula; it has been, and still is, researched by renowned national and international geologists, geomorphologists, botanists, zoologists, archeologists and his-

\footnotetext{
${ }^{1}$ Members of the Working Team for the establishment of Djerdap Geopark: dr Dragoman Rabrenović, Marica Knežević (Serbian Geological Survey), Mališa Mladenović, Aleksandra Došlić, Lidija Stevanović (Ministry of Environmental protection of the Republic of Serbia), dr Danica Srećković-Batoćanin (Faculty of Mining and Geology, University of Belgrade), dr Aleksandra Maran Stevanović (Natural History Museum in Belgrade), dr Jelena Ćalić (Geographical Institute „Jovan Cvijić“, SASA), Srdjan Marinčić (Institute for Nature Conservation of Serbia), Nenad Radaković, Sanja Manojlović, Zoran Milovanović, Dragan Drndarević (Djerdap National Park), Jelena Milenković (Ministry of Mining and Energy of the Republic of Serbia), Irena Vulić (Ministry of Construction, Transport and Infrastructure of the Republic of Serbia).
} 
torians. Achievements and results of their research are documented in a wide range of scientific, expert and popular publications.

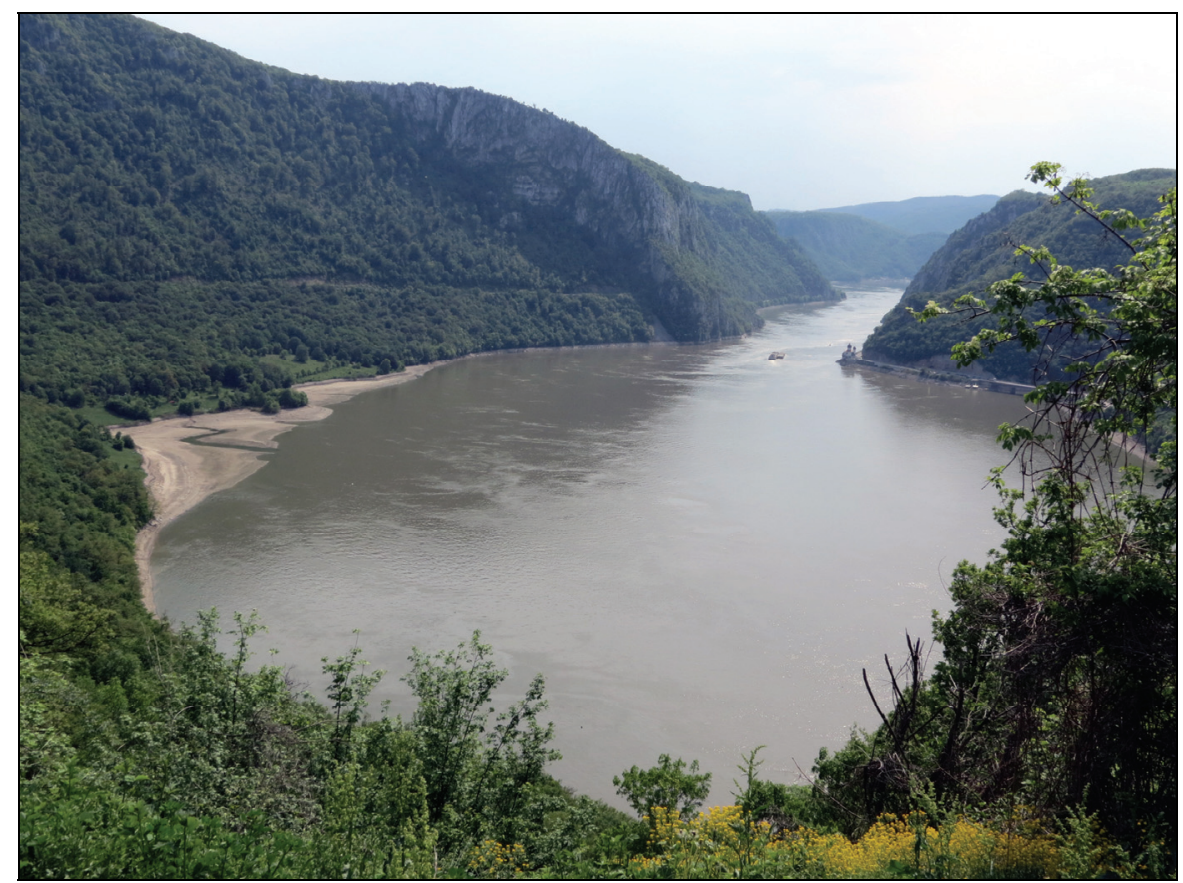

Fig. 2. - Djerdap Gorge from Golo Brdo viewpoint (photo: Z. Stevanović)

\section{GEODIVERSITY}

From geological point of view, the area of aspiring geopark belongs to the Carpathian-Balkanides of eastern Serbia, which represent the northern Alpine branch formed under highly varied geological conditions, including intensive uplifting, fracturing, secondary erosion modification and intensive karstification processes (Maran Stevanović \& Srećković Batoćanin 2017). Several geological entities can be distinguished in this area, each with complex tectonic structures and lithology.

The oldest rocks are the Precambrian amphibolite facies that originated from deeper parts of the Earth's crust. The Paleozoic units consist of the Lower Cambrian volcano-sedimentary rocks, Ordovician schists, Carboniferous marine and continental deposits and Permian red sandstones and spilites (Grubić 1980, 1997, Krstić \& Maslarević 1997). These deposits were highly tectonized and metamorphosed due to the large tectonic movements of the Variscan orogeny.

During the Jurassic, the entire area was invaded by marine transgression and the sedimentation cycle continued until the beginning of Upper 
Cretaceous. The Jurassic limestones, marls and cherts, Lower Cretaceous claystones, marlstones, sandstones and limestones and early Upper Cretaceous conglomeratic limestones, sandy claystones and thin bedded marlstones were formed during this period (Grubić 1980, Rabrenović 1997, Rabrenović \& Vasić 1997).

In the adjacent area, deposition of the Upper Cretaceous rocks was accompanied by a multiphase magmatism, and thus produced a huge volcanogenic-sedimentary series - the Timok Magmatic Complex, over 2.000 meters thick (Banješević 2010). During the Paleogene, intrusive igneous rocks were formed following geodynamic evolution of the Carpathian orogen. In the Oligocene, several fresh-water basins existed along the main longitudinal faults. The Miocene, dominantly Badenian marine sediments were deposited within the 'trans-Carpathian strait system', which connected the Western (Pannonian) and the Eastern (Dacian-Black Sea) provinces of the Paratethys (Stevanović 1990, Knežević 1997). Fluvial, slope and cave deposits are formed during the Quaternary.

The geoheritage list includes 63 proposed geosites that testify type sections of geological units, illustrations of tectonic processes, fossiliferous localities, representative landforms and effects of weathering, erosion or landform evolution, unusual mineral occurrences or sites of exceptional natural beauty. The importance and value of selected geoheritage were assessed based on the attributes of each particular phenomenon, including how representative it is, how valuable it is in terms of science, education, geoconservation and tourism, how vulnerable it is to potential threats as well as by its comparison with the similar sites at the international, national, regional and local level (Maran Stevanović 2015).

The category 'internationally important geosites' is assigned by members of the Working Team for the establishment of Djerdap Geopark to five sites, namely Djerdap Gorge, Pesača, Greben ridge, Boljetinsko Brdo and Vratna natural bridges. Djerdap Gorge is the most complete manifestation of geodiversity and biodiversity phenomena, which along with cultural-historical heritage signifies an integrated natural and cultural resource not only in Serbia but also in Europe.

The sites Pesača, Boljetinsko Brdo and Greben ridge (Figure 3) altogether represent unique sedimentological-paleontological complex that illustrates a part of geological history of the Tethys Ocean during Jurassic-Lower Cretaceous time. The most significant outcrop for scientists and researchers refers to the Lower, Middle and Upper Jurassic lithological units occurring at the road section Pesača (Figure $3 \mathrm{c}$ ). Abundant remains discovered at this section include fossilized brachiopods, bivalves, ammo- 
nites and belemnites. Boljetinsko Brdo is one of the most scientifically important sites simply because it depicts the Lower Cretaceous (Upper Barremian) deep-water sediments where new genera and species of ammonites were identified (Figure 3d) (Vašíček et al. 2014). An impressive profile of the Middle Jurassic reddish, nodular marly limestones rich in fossils is exposed at the Greben ridge (Figure 3e); this site is considered to be the best exposure of Jurassic-Lower Cretaceous succession in this part of Carpathian-Balkanides.

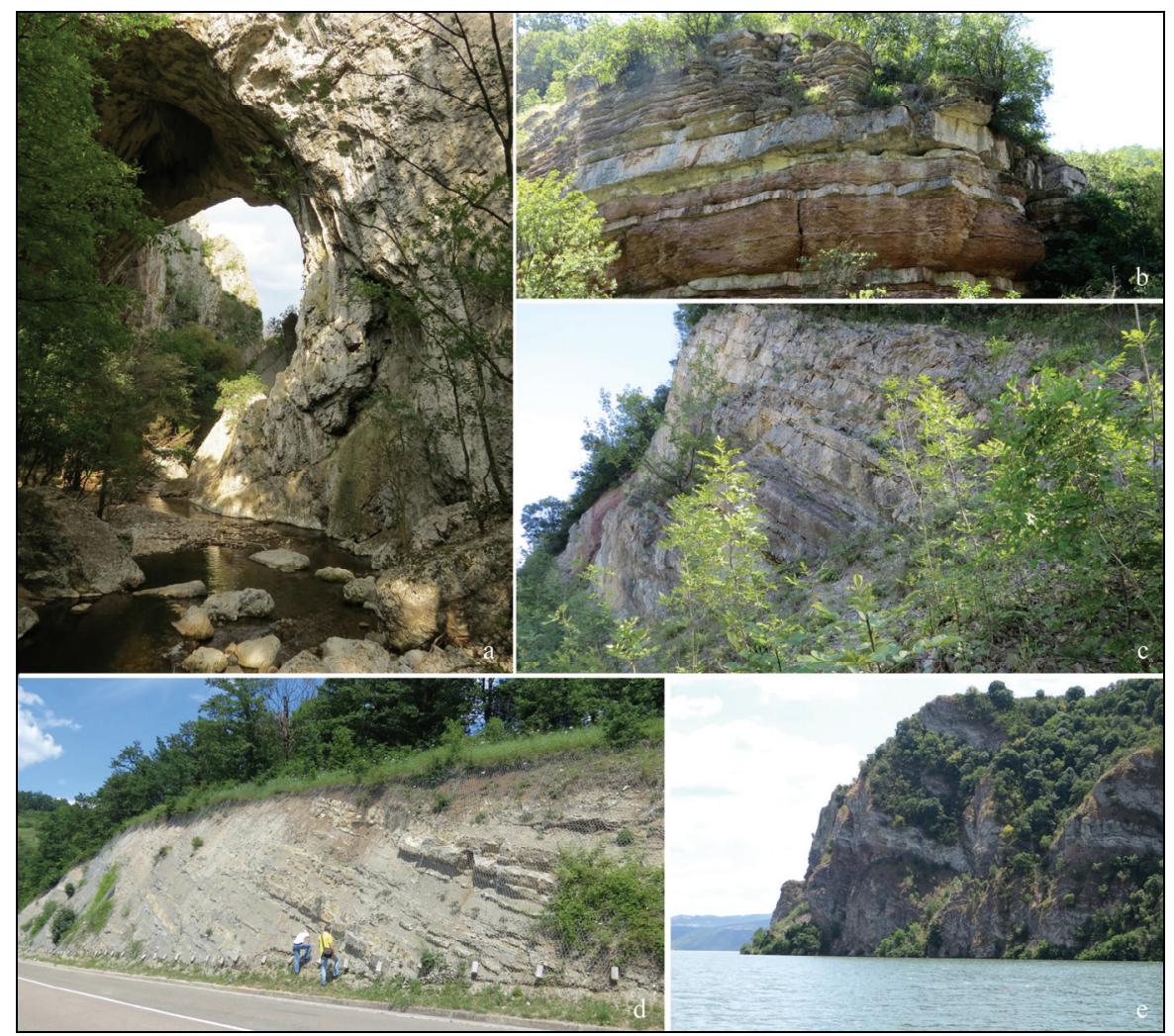

Fig. 3. - Geodiversity of Djerdap Gorge: a) Vratna stone-bridge, b) Boljetinska Reka Gorge, c) part of Pesača section, d) Boljetinsko Brdo, e) Greben ridge (photo: A. Maran Stevanović)

Natural monument Prerasti Vratne represents the best preserved karstic geomorphological feature of such a type in Serbia and very rare phenomenon in term of the state of preservation in the southeastern Europe (Figure 3a). It includes the Small, the Great and the Dry natural bridges (in Serbian: Mala, Velika, Suva Prerast) along the Vratna River gorge. Their origin can be explained through the dissolution of limestone in water and a partial collapse of the former caves ceiling. 
The category 'nationally important geosites' is assigned to eight sites: Boljetinska Reka Gorge (Figure 3b), Traces of Carpathian Strait, RidanGolubac, Peridotites of Miroč, Rakin Ponor, Korešin Potok, Gradašnica Cave and Rajkova Pećina Cave. Due to their significance for the development of geology and geomorphology in Serbia, they have been used as reference sites by the national scientific community.

The most significant geological collections, containing specimens from the Djerdap area have been gathered as the result of lengthy geological investigations and museological works. They are kept in the Natural History Museum in Belgrade, the Faculty of Mining and Geology, University of Belgrade and the Serbian Geological Survey. Some of these specimens signify geological and museological rarities because they derived mostly from sites, which have been destroyed or are no longer accessible (partially submerged by the artificial Djerdap Lake) and represent an important resource that cannot be replaced (Figure 4).

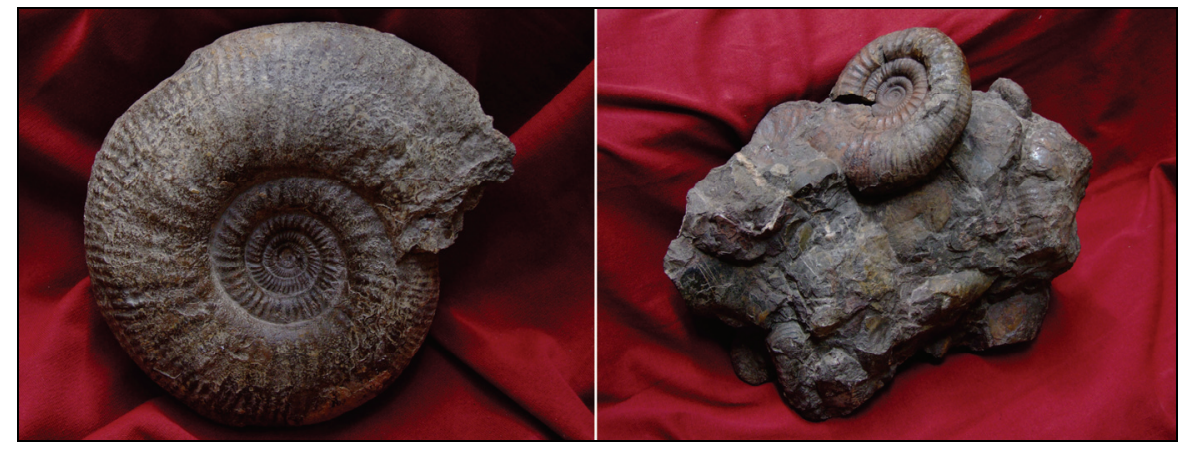

Fig. 4. - Ammonites from Greben ridge (Mesozoic Invertebrate Collection, Natural History Museum in Belgrade) (photo: A. Maran Stevanović)

\section{BIODIVERSITY}

Geopark area belongs to one of the largest and the most northerly European refugees for Tertiary flora, with more than 50 different types of forest and bush communities, out which 35 are relict (source: Red data book of Flora of Serbia). Representatives of approximately 1100 vascular plants inhabit this territory (Stevanović 1996). Well-developed polydominant forests mainly consist of Tertiary relicts: beech, walnut, Turkish filbert, yew, linden, Caucasian lime, nettle tree, common lilac and common holly. The representatives of 16 Balkan endemics can be found here, including Pančić' maple, endemic variant of hawkweed, viola, thyme, bear's breeches, mouse-ear chickweed, bellflower, and others (source: Institute for Nature Conservation of Serbia). 
Approximately 150 bird species are registered in the area, but this number is not final (source: Djerdap National Park, Institute for Nature Conservation of Serbia). Among the most important representatives are pygmy cormorant, lesser spotted eagle, booted eagle, white-tailed eagle, golden eagle, peregrine falcon, corncrake, black stork, the Eurasian eagle-owl, the Ural owl, the Eurasian scops owl, the Alpine swift, red-rumped swallow and others. Due to the diversity of birds and the presence of rare, endangered bird species, the area of Djerdap National Park has been declared an Important Bird Area (IBA).

The abundance of mammals is largely due to the well-preserved habitats; representatives of species such as otter, wildcat, Eurasian lynx, brown bear, chamois, deer, roe deer and different bats are specified within the Preliminary Red List of Vertebrates of Serbia (Vasić et al. 1991). The richness of vegetation influenced a high diversity of butterfly fauna, for which the Djerdap area is assigned an internationally important Prime Butterflies Area (PBA) (Jakšić 2008). Today, about 60 fish species are reported in the Danube Gorge (source: Djerdap National Park). The most notable representatives are catfish, zander, pikeperch, sterlet, common bream, the European chub, common barbell and asp. However, Lendhardt and others (2004) indicate that many native species, including sturgeon, common carp, common barbell, zander and catfish, have been decreasing since the construction of dams Djerdap I and II.
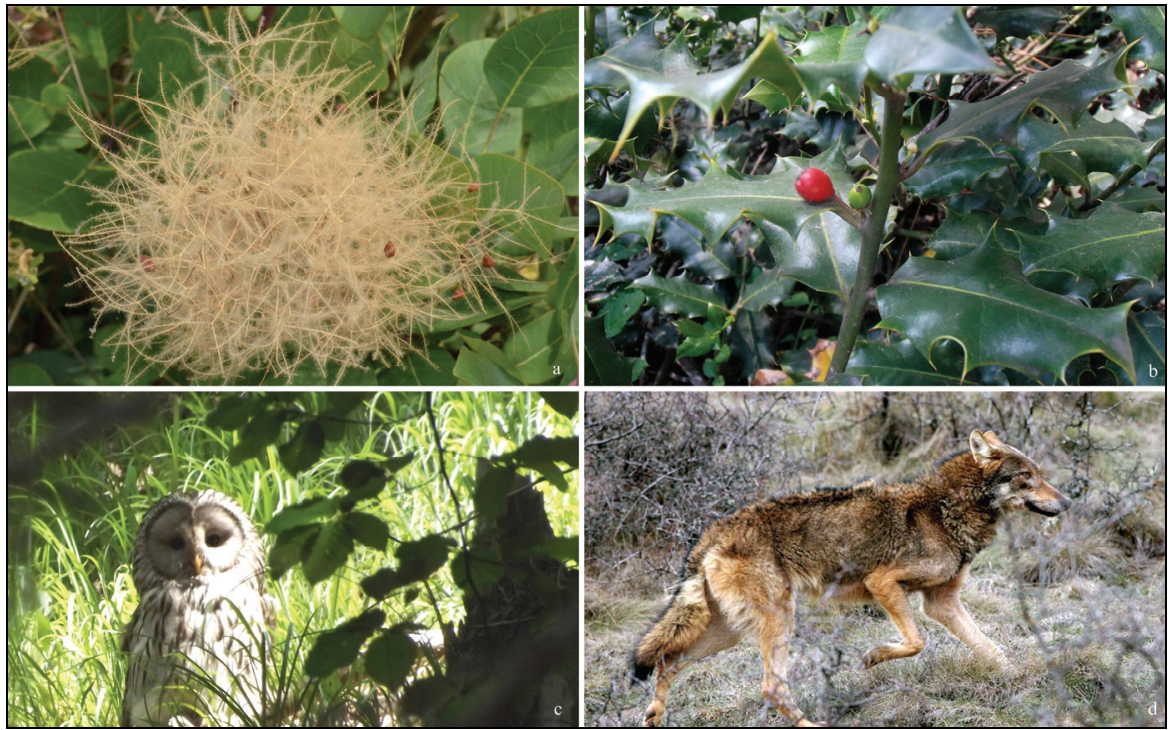

Fig. 5. - Biodiversity representatives of Djerdap Gorge: a) the European smoke tree, b) common holly, c) the Ural owl, d) wolf (photo: A. Maran Stevanović \& S. Marinčić) 
Decree on the Spatial Plan for the Special Purpose of the National Park Djerdap (Official Gazette of RS, no. 43/2013) was prepared and adopted aiming to create conditions for the realization of national, regional and local interests in the planned area in line with the protection and preservation of special natural values, significant cultural heritage as well as their arrangement and functional usage based on the principles of sustainable development. According to this Spatial Plan, fourteen areas are selected within the first protection zone of the Park: 1) Golubac, 2) Bojana, 3) Bosman-Sokolovac, 4) Brnjica River Gorge 5) Čoka Njalta-Pesača, 6) Lepenski Vir, 7) Boljetin River-Greben, 8) Tatarski Vis, 9) Šomrda, 10) Ciganski potok stream, 11) Veliki and Mali Štrbac with Tabula Traiana, 12) Gradašnica, 13) Kovilovo and 14) Tilva Toma. Certain protected areas are part of some already existing international programmes: Important Bird Areas (IBA), Important Plant Areas (IPA), Prime Butterfly Areas (PBA), Emerald network of Areas of Special Conservation Interest and European Green Belt. Two areas, namely Mala Vrbica and Vinci-Usije are in nomination process for the inscription in the List of Wetlands of International Importance (the Ramsar List).

\section{CULTURAL HERITAGE}

Djerdap area is also known, nationally and internationally, for its exceptional cultural and historical monuments dating from the Mesolithic period to modern times. Certainly, the most significant and valuable representative of the cultural heritage is the archeological site Lepenski Vir, named after the great whirlpool in the Danube middle course (Srejovic 1972). It contains settlements from different periods: the Early Mesolithic (Proto Lepenski Vir, 9500-7500 BC); Late Mesolithic (Lepenski Vir Ia-e and Lepenski Vir II, 6300-5900 BC) and Early Neolithic period (Lepenski Vir IIIa-b, 5900-5500 BC). As the archeological site was discovered in the zone which was planned to be submerged by reservoir water of the hydroelectric plant Djerdap, the remains of the houses and shrines were moved together with associated artifacts to a new location, above and away from the original one (Figure 6).

The prehistoric site Rudna Glava, located nearby the town of Majdanpek, offers well-preserved evidence of early copper mine works that provided an important insight into the prehistoric mining activities in Europe (Filipović 2015). Mine shafts were carved into the hillside, with scaffolding constructed for easy access to the ore veins. Radiocarbon dating indicates that the mine was in use throughout the late 6th and first half of the 5th millennium BC - during the regional Late Neolithic period and spanning the entire duration of the Vinča culture. 


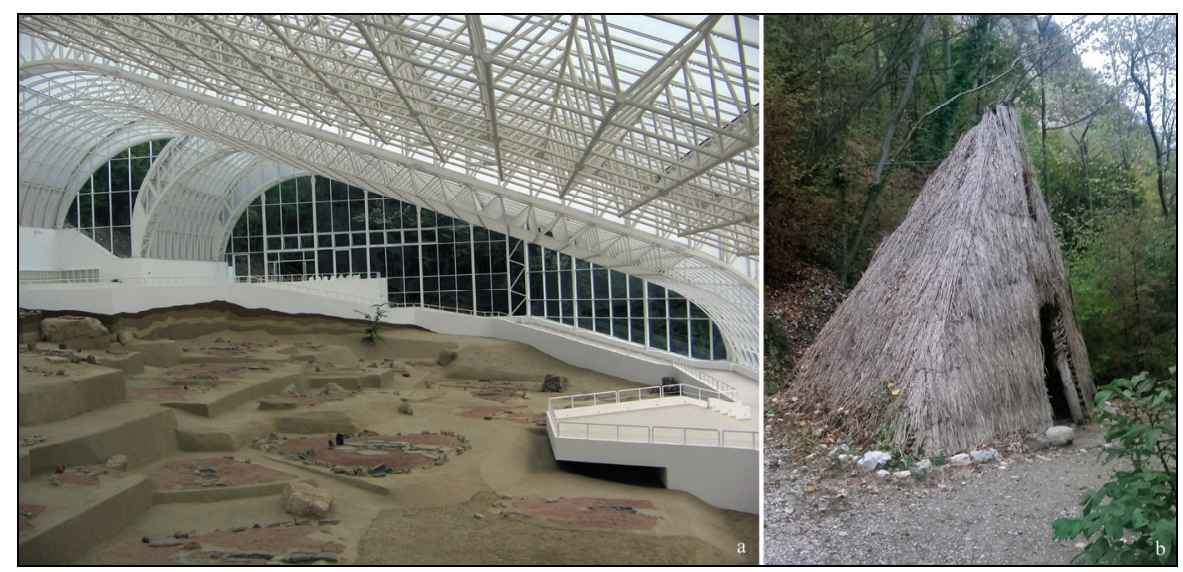

Fig. 6. - Archeological Museum Lepenski Vir: a) reconstructed site-interior, b) reconstructed house outside after Srejović (photo: A. Maran Stevanović)

The area along the Danube had been an important trade route and connection between the Western and Eastern territories of the Roman Empire; among the oldest material evidences are the Trajan's Plaque (Tabula Traiana), the remains of Trajan's Bridge and Diana Fortress (Figure $7 \mathrm{a}, \mathrm{b}, \mathrm{d}$ ). The Trajan's Plaque was erected in honor of the completion of construction of the road, the enthronement of Roman emperor Nerva Trajan in the sector of the Lower Danube, and his march on Dacia. Few kilometers downstream from Kladovo stand the remains of Trajan's Bridge. According to data provided by Roman historian Cassius Dio, it was a high stone bridge with 20 piers in water connected by arches. It is recorded that the Emperor Hadrian, Trajan's successor, ordered demolition of its upper structure to prevent barbarian attacks. Diana Fortress is located in the Karataš archeological site near Kladovo. The main buildings are constructed on a strategic location overlooking the Danube frontier in $100 \mathrm{AD}$, during the reign of Emperor Trajan who picked up a military camp in the vicinity. At the mid of 4th century, the fort was damaged by the invading Huns and in $530 \mathrm{AD}$, rebuilt by Emperor Justinian.

Djerdap area is also recognizable among the tourists by the remains of recently reconstructed Golubac Fortress (Figure 7c), a medieval fortification which 'welcomes' the visitors at the very entrance to the gorge, and Fetislam, the Turkish fortification at the exit. The Golubac fortress with its nine towers has been erected on rocky cliffs few kilometers downstream from the town of Golubac. Situated westwards from the modern town of Kladovo, the medieval Fetislam consists of two separate units, the Small and the Large Fort that were built in different periods as well as with different concepts and fortification characteristics (source: Danube Virtual 
Museum). Both medieval fortifications testify the constant clashes of various cultures and civilizations in the region.
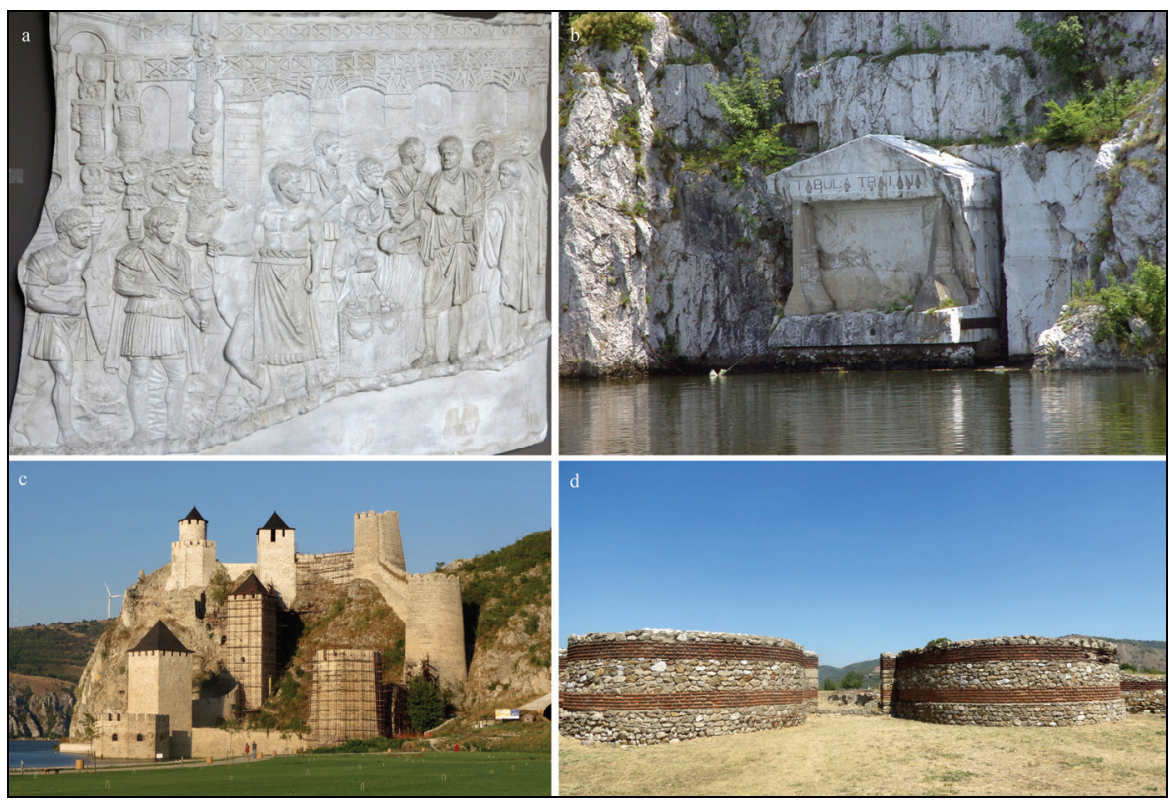

Fig. 7. - Cultural heritage: a) copy of the relief of Trajan's Column in Rome showing the Trajan's Bridge on the Danube (Archeological museum of Djerdap in Kladovo), b) Trajan's Plaque, c) Golubac Fortress, d) Diana Fortress (photo: A. Maran Stevanović \& D. Milovanović)

\section{HUMAN RESOURCES}

Geopark comprises the territory of four municipalities (Golubac, Majdanpek, Kladovo and Negotin), which belong to the administrative districts of Bor and Braničevo, respectively. As the entire region of eastern Serbia, the geopark area is also characterised by an unfavourable demographic trend and population density - fewer than 30 inhabitants per square kilometre, and by critically high average age of the population (44.6 years) (Maran Stevanović 2017).

The largest hydropower dam and reservoir system along the entire Danube River Basin - the Djerdap Hydropower Plant System is located at the Djerdap Gorge. It consists of two dams (Djerdap or Iron Gate Dam I and II), which main activities are the electricity production and provision of services to river and lake transport, particularly the navigation of boats through the dam canal system. The Djerdap I hydropower plant was built between 1964 and 1972, 943 kilometers from the confluence of the Danube into the Black Sea (source: International Commission for the Protection of 
Danube River/ICPDR 2016). The Djerdap II is the second largest hydropower plant on the Danube River between Serbia and Romania, constructed in the period 1977-2000. It is located 863 kilometers from the Danube Black Sea delta. As the Djerdap I, this system also represents complex and multipurpose hydrotechnical facility (source: Electric Power Industry of Serbia).

As indicated by Macura and others (2013), flooding the area had many negative social effects: the majority of arable land was submerged; villagers were removed to less fertile land and changed their way of life; settlements lost their municipal status; administration centres were relocated to neighboring cities. The growth rate has been declining since the early 1980s, which is reflected consequently in the rapid aging of the population, the abandonment of rural settlements, and deficiency in the agricultural labor force. Poor economic situation in the entire country in the past two decades contributed to intensive migration of local residents to urban centres and abroad, particularly the younger population.

To achieve socio-economic recovery and develop the population, it is necessary to stimulate and activate the existing tourist and economic potentials: improve and supplement the tourist offer with new content and activities, invest in and develop agricultural production, revitalize old crafts, and better place for traditional products. This would provide conditions for work and employment of the local communities, especially the younger generation, and prevent further downward population trend (Maran Stevanović 2017).

\section{RECENT ACTIVITIES ON THE ESTABLISMENT OF DJERDAP GEOPARK}

Establishing potential geopark is a long-lasting process, implemented in stages. It includes planning, organization and set comprehensive actions toward desired outcomes. The initial phase, conducted in 2015, was involved the identification of geopark area and its boundaries, establishment of appropriate management structure and expert teams, cooperation with representatives of local authorities, local communities and local private sector.

During 2016, members of the Working Team for the establishment of Djerdap Geopark accomplished detailed research to appraise situation in the field, identify risk factors and the level of vulnerability of geological and cultural-historical sites, in order to timely undertake necessary measures and actions to improve the preservation of these objects. Arranging the sites and their surroundings carried out during the early 2017 
and the first 20 selected geosites, including both internationally and nationally significant, were prepared for tourists ${ }^{2}$.

The nomination process of Djerdap Geopark also took place in stages. In line with clearly defined Operational Guidelines for the UNESCO GGN, as a mandatory first step, members of the Working Team submitted the letter of intent through the official channel - the National Commission for relation with UNESCO. The preparation of comprehensive application dossier started at the beginning of 2016, and included the fulfill of five main sections: A) Identification of the area, B) Geological heritage, C) Geoconservation, D) Economic activity \& business plans and E) Interest and arguments for becoming a UNESCO Global Geopark. Application file also entailed the following required annexes: 1) self-evaluation document, 2) repeated section of the geological heritage, 3) an endorsement of relevant local and regional authorities and a letter of support from the National Commission for UNESCO, 4) a large scale map of the proposed UNESCO Global Geopark showing clearly defined boundary of the proposed geopark with all marked towns and villages, sites of valuable natural and cultural heritage and tourism facilities and 5) geological and geographic summary with a detailed map and standard UN geographical maps with the geopark location. The final point in nomination procedure was submission of the formal request for membership. With minor revisions, the dossier was accepted in early 2017 , and, in the middle of the year, experts from UNESCO GGN were appointed for evaluation in the field. The field evaluation mission was carried out at the beginning of August 2017 (Figure 8), with positive appraisal. However, the evaluation process for the Djerdap area has not been completed yet due to decision of the UNESCO Global Geoparks Council to defer this candidature for a maximum of two years to allow for improvements to be made to the quality of the application.

\section{CONCLUDING REMARKS}

The Djerdap aspiring geopark has the opportunity to become a unique natural laboratory - an open-air museum in which geological, ecological and civilization history of this part of southeast Europe will be presented and interpreted to visitors in an exciting and engaging way. Real sustainable development of the region can be obtained through various tourism activities, since the concept of the Djerdap Geopark offers visitors

2 Site-preparation included: vegetation removal, cleaning of crumbled fragments, preparing and setting up the information panels and making the pathways (access roads, parking and sanitary facilities). 


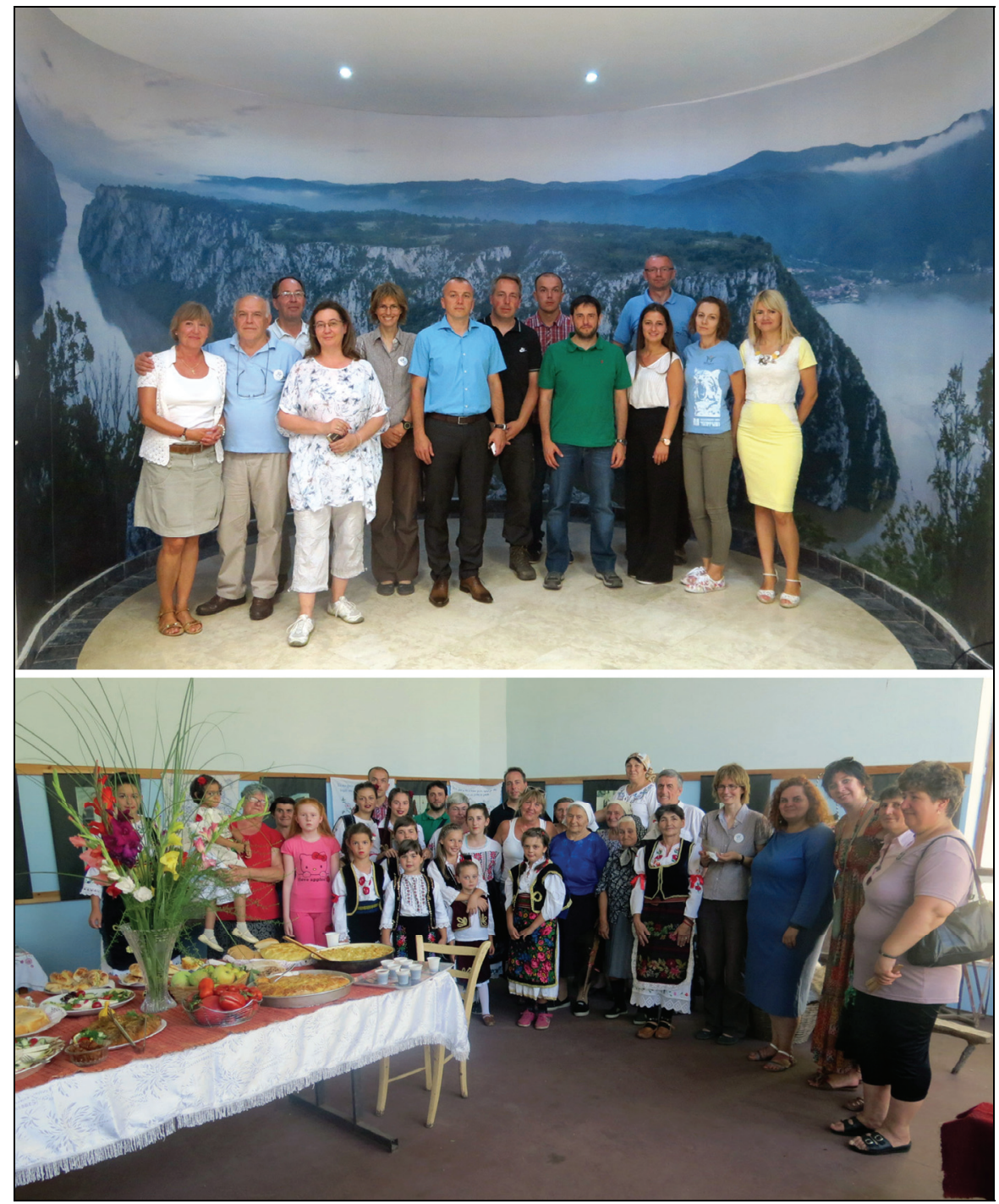

Fig. 8. - Members of the Working Team with evaluators from the UNESCO GGN (above) and representatives of local community from Dobra village (below) (photo: A. Maran Stevanović)

a wide range of possibilities: to see, walk, touch, perceive and enjoy one of the geologically, historically and culturally richest regions in Serbia. In direct and active contact with nature, it is expected that visitors will learn about local plants and animals and their habitats, as well as the environment of prehistoric man, and thus understand the unbreakable link between the abiotic and biotic components of nature. 
Tourism presents a major challenge to the Djerdap area, but it is also an opportunity for local and regional development. As the needs and interests of tourists shifted in the last ten years toward acquisition of new skills and knowledge, popular educational programmes in geology and other earth sciences can complement and simultaneously raise the level of the existing tourist offer. It is an undisputed fact that nature and natural resources are what attracts most tourists, and that is where all available human, technical and technological resources should be directed. Particular attention should be paid to long-term planning of educational programmes to protect nature and the environment at the local level, in order to enhance the knowledge and raise awareness of the local population and representatives of the local governments about the natural resources and opportunities for economic development and prosperity that can come from sustainable use of natural resources.

The following have been identified as priority tasks: media promotion of geoheritage sites, tracing and marking new hiking routes (georoutes), planning and organizing educational and tourist programs for different target groups, preparing action and financial plans as well as allocating financial resources for implementation of planned actions.

The main advantages of Djerdap are: unpolluted environment; diversity of natural resources, geological in particular; attractive landscapes; rich flora and fauna; numerous cultural and historical attractions; and kindness and hospitality of local residents. The significance of admission of this area in the UNESCO Global Geoparks would be manifold: it would raise awareness of the local population about nature protection and strengthen their identity, provide an opportunity to exchange ideas, strategies and experiences concerning the protection and conservation of nature and natural resources with other geoparks, while the Geopark would acquire the trademark that would make it known throughout the world.

\section{Acknowledgments}

My most cordial thanks go to my colleagues, members of the Working Team, who have offered their knowledge, great energy and enthusiasm in all the preparatory activities related to the founding of Djerdap geopark. I am also grateful to Mr. Lazar Mitrović, Director of the Djerdap National Park and the NP staff for their fruitful long-term cooperation. Special thanks go to the representatives of local communities, local authorities and local tourist agencies, as well as volunteers Dobrila Lukić and Manuela Graf for their altruistic assistance and energy invested in the course of the evaluation mission. 


\section{REFERENCES}

Banješević, M. (2010): Vulcanological characteristics of the Upper Cretaceous rocks of the Timok Magmatic Complex. - In: Banjac, N., Maran, A., Savić, Lj., Cukavac, M., Ganić, M. (eds): Proceedings of the $15^{\text {th }}$ Congress of geologists of Serbia with international participation, Belgrade 26-29 May 2010: 1-6.

Grubić, A. (1980): Yugoslavia. An outline of Geology of Yugoslavia. In: $26^{\text {th }}$ International Geological Congress, Guide book 15: 5-49. - Paris.

Grubić, A. (1997): Upper Cretaceous of Gethic Unit. - In: Grubić, A., Berza, T. (eds): Geology of Djerdap area, International symposium "Geology in the Danube gorges" Yugoslavia and Romania, Donji Milanovac/Orsova, 23-26. IX 1997, Special publication 25: 59-60.

Filipović, D. (2015): Rudna Glava in the Foreground of Recent Overviews of the Beginnings of Copper Mining in Europe and of the Development of Archaeometallurgy. Institute for Balkan Studies, Serbian Academy of Sciences and Arts, Balcanica 46: 341-347.

Institute of Architecture and Urban and Spatial Planning of Serbia (2012): Spatial Plan for the Special Purpose Area of the National Park "Djerdap". - Belgrade, 127 pp. [in Serbian]

Jakšić, N. (2008): Developing methods for target species and Prime Butterfly Areas selection criteria in Serbia. Bulletin of the Natural History Museum 1: 205-228

Knežević, S. (1997): The Neogene of Djerdap and West of Golubac. - In: Grubić, A., Berza, T. (eds): Geology of Djerdap area, International symposium "Geology in the Danube gorges" Yugoslavia and Romania, Donji Milanovac/ Orsova, 23-26. IX 1997, Special publication 25: 65-70.

Krstić, B., Maslarević, Lj. (1997): The Paleozoic of Djerdap. - In: Grubić, A., Berza, T. (eds): Geology of Djerdap area, International symposium "Geology in the Danube gorges" Yugoslavia and Romania, Donji Milanovac/Orsova, 23-26. IX 1997, Special publication 25: 25-29.

Lenhardt, M., Cakić, P., Kolarević, J. (2004): Influence of the HEPS Djerdap I and Djerdap II dam construction on catch of economically important fish species in the Danube River. - Ecohydrology \& Hydrobiology 4: 499-502.

Macura, B., Bojović, P., Petrić, I., Ćosić, N., Tadić, M., Jarić, I., Knežević, J., Špirić, J., Jarić M. (2013): Local communities and management of the Djerdap protected area in Serbia. - In: Healy, H., Martinez-Alier, J., Temper, L., Walter, M., Gerber, J-F. (eds): Ecological economics from ground up: 366-390. - Rutledge Taylor \& Francis Group.

Maran, A. (2010): Geoparks - European experience and perspectives. - In: Banjac, N., Maran, A., Savić, Lj., Cukavac, M., Ganić, M. (eds): Proceeding of the 15 th Congress of geologists of Serbia with international participation, Belgrade 26-29 May 2010: 702-708. 
Maran Stevanović, A. (2015): Methodological guidelines for geoheritage site assessment: a proposal from Serbia. - Geološki anali Balkanskoga poluostrva 76: 105-113.

Maran Stevanović, A. (2017): Djerdap Geopark. Economic activities \& Business plan (parts D and E). - Application dossier for membership in the UNESCO Global Geoparks Network, 14 pp.

Maran Stevanović, A., Ćalić J. (2017): Djerdap Geopark. Identification of the area (part A). - Application dossier for membership in the UNESCO Global Geoparks Network, 6 pp.

Maran Stevanović, A., Srećković Batoćanin, D. (2017): Djerdap Geopark. Geological heritage (part B). - Application dossier for membership in the UNESCO Global Geoparks Network, 15 pp.

Mc Keever, P., Zouros, N. (2005): Geoparks: Celebrating Earth heritage, sustaining local communities. - Episodes 28(4): 274-278.

Rabrenović, D. (1997). Lower Cretaceous Stratigraphy of Danubicum. - In: Grubić, A., Berza T. (eds): Geology of Djerdap area, International symposium "Geology in the Danube gorges" Yugoslavia and Romania, Donji Milanovac/ Orsova, 23-26. IX 1997, Special publication 25: 47-55.

Rabrenović, D., Vasić, N. (1997). Characteristics of Jurassic and Lower Cretaceous of Geticum-Golubac Mts. - In: Grubić, A., Berza T. (eds): Geology of Djerdap area, International symposium "Geology in the Danube gorges" Yugoslavia and Romania, Donji Milanovac/Orsova, 23-26. IX 1997, Special publication 25: $36-40$.

Srejović, D. (1972). Europe's First Monumental Sculpture: New Discoveries at Lepenski Vir. - London.

Stevanović, V. (1996): Samonikla botanička bašta. - In: Angelus, J. (ed.) Nacionalni park Djerdap - Pamtivek prirode i čoveka: 72-82. - IP Ecolibri, Ministarstvo zaštite životne sredine \& Nacionalni park Djerdap, Beograd. [in Serbian]

Stevanović, P. (1990): Faciostratotipen in Bosnien, Serbien und Syrmien. - In: Malez, M., Stevanović, P. (eds): Chronostratigraphie und Neostratotypen, Neogen der Westlichen (“Zentral”) Paratethys, 8, Pl1 Pontien: 439-457. Jugoslawischen Akademie der Wissenschaften und Künste und der Serbichen Akademie der Wissenschaften und Künste, Zagreb-Beograd.

Vasić, V., Džukić, G., Janković, D., Simonov, N, Petrov, B., Savić, I. (1991): Preliminarni spisak za Crvenu listu kičmenjaka Srbije / Preliminary Red List of Vertebrates of Serbia. - Zaštita prirode 43-44: 121-132. [In Serbian with English summary]

Vašíček, Z., Rabrenović, D., Skupien, P., Radulović, V., Radulović, B., Mojsić, I. (2014): Ammonites (Phylloceratoidae, Lytoceratoidea and Ancyloceratoidea) and noncalcareous dinoflagellates from the Late Barremian of Boljetin, eastern Serbia. - Cretaceous Research 47: 140-159. 


\section{USEFUL LINKS AND DOCUMENTS}

Danube Virtual Museum

Available at http://www.virtuelnimuzejdunava.rs/serbia.322.html

Accessed: 05/2016

Decree on the Spatial Plan for the Special Purpose of the National Park Djerdap, Official Gazette of the Republic of Serbia, 43/2013. [in Serbian]

Djerdap National Park

http://www.npdjerdap.org

Electric Power Industry of Serbia (EPS), 2009: Environmental Protection, Belgrade, Serbia.

Available at http://www.eps.rs/Eng/Documents/EPS\%20Environment\%20 protection.pdf

Accessed: 10/2016

European Geoparks Network

http://www.europeangeoparks.org

Institute for Nature Conservation of Serbia http://www.zzps.rs

International Commission for the Protection of Danube River (ICPDR), 2016: Serbia Facts and Figures.

Available at https://www.icpdr.org/main/danube-basin/serbia

Accessed: 09/2016

Red data book of Flora of Serbia, volume 1-Extinct and critically endangered taxa.

Ministry of Environment of the Republic of Serbia, Faculty of Biology, University of Belgrade, Institute for protection of nature of the Republic of Serbia, Belgrade, 1999

UNESCO Global Geoparks Network

http://www.unesco.org/new/en/natural-sciences/environment/earth-sciences/ unesco-global-geoparks 


\title{
АКТИВНОСТИ НА УСПОСТАВЉАҢУ ГЕОПАРКА ЂЕРДАП (СРБИЈА) И КАНДИДАТУРА ПОДРУЧЈА У UNESCO ГЛОБАЛНУ МРЕЖУ ГЕОПАРКОВА
}

\author{
АЛЕКСАНДРА МАРАН СТЕВАНОВИЋ
}

\section{Р Е 3 И М Е}

Геопарк је територија јасно дефинисаних граница у оквиру које се штите, презентују и промовишу не само међународно значајни објекти геонаслеђа већ и све друге природне и културно-историјске знаменитости. Активности у геопарку усмерене су на упознавање шире јавности о разноврсним природним и културним вредностима датог подручја кроз развој (гео)туризма са циљем да се побољша социо-економски статус локалних заједница, подстакне ьихов економски развој и унапреди заштита материјалне и нематеријалне баштине. Геопарком управља одговарајуће организационо тело које, у складу са националним законодавством, координира рад и активности у домену геозаштите и спроводи политику одрживог развоја на његовој територији. Активности у геопарку углавном се финансирају из националних и локалних извора, уз могућност коришћења развојних фондова Европске Уније.

Чланови Радне групе за оснивање националних геопаркова у Србији, која је формирана почетком 2014. године под окриљем Министарства пољопривреде и заштите животне средине, анализирали су природне, културне, научне, образовне и туристичке потенцијале појединих подручја у Србији. На основу процене издвојених перспективних региона, постигнут је договор да се први геопарк успостави на подручју Ђердапа и да се управо ово подручје кандидује у UNESCO Глобалну мрежу геопаркова.

Потенцијални геопарк Ђердап налази се у североисточној Србији; река Дунав уједно представља природну и административну границу између Републике Србије и Румуније. Геопарк обухвата територију од 1.330 квадратних километара, укључујући и подручје Националног парка Ђердап, који је основан 1974, али превазилази његову територију за додатних 692 квадратна километра. Састоји се од приобалног појаса Ђердапске клисуре у средњем току Дунава и његовог залеђа делова планинских масива Кучај и Мироч.

Ђердапска клисура је најмаркантнији природни феномен на подручју предложеног геопарка. На свом путу од Голупца до Кладова, на 
дужини од 117 километара, Дунав се усеца у обод Јужних Карпата, спајајући Панонски басен на западу и Дакијски басен на истоку. Дуж клисуре откривени су бројни непокретни и покретни објекти геонаслеђа из готово свих периода геолошке историје, од протерозоика до данас. Ово је уједно и једно од најбоље проучених подручја Балканског полуострва, које су истраживали и дан-данас истражују реномирани национални и интернационални геолози, геоморфолози, ботаничари, зоолози, археолози и историчари. Њихова достигнућа и резултате проучавања документује широк спектар научних, стручних и популарних публикација. Координацију активности у оквиру будућег геопарка спроводиће Јавно предузеће Национални парк Ђердап, које од 1993. године реализује концепт управљања овим заштићеним подручјем, уз континуирану помоћ и подршку два новооснована савета - Стручног и Техничког.

Успостављање потенцијалног геопарка дуготрајан је процес који обухвата планирање, организацију и реализацију свеобухватних активности у складу са постављеним циљевима. У иницијалној фази спроведеној током 2015, чланови Радног тима за формирање геопарка Ђердап (координатор М. Младеновић, Група за заштићена подручја у оквиру Министарства) дефинисали су границе подручја, определили одговарајућу управљачку структуру и тимове стручњака, успоставили сарадњу са представницима локалних самоуправа, локалног становништва и локалног приватног сектора и дефинисали прелиминарне научне, едукативне и туристичке програме. У другој фази приступило се евалуацији потенцијалних елемената природног и културног наслеђа, посебно објеката геонаслеђа, као и процени затеченог стања, фактора ризика и степена угрожености. На основу добијених резултата, спроведена је категоризација (међународни, национални, регионални и локални ниво) и издвојени репрезентативни објекти са предлозима и сугестијама за примену одговарајућих заштитних метода и мера.

У периоду 2016-2017, за туристе је уређено 20 првоизабраних објеката геонаслеђа као и простор око самих објеката (прилази и приступне стазе, припрема и постављање информативних табли). Сагласно критеријумима и процедурама за приступање UNESCO Глобалној мрежи геопаркова, у овом периоду извршена је припрема обимног апликационог досијеа са неопходном пратећом документацијом и поднесен званичан захтев за чланство у Мрежу геопаркова. Почетком 2017, уз мање измене и допуне, апликациони досије прихваћен је од стране Секретаријата Мреже, а средином ове године одређени су чланови евалуаторске комисије, који су почетом августа извршили процену на терену и позитивно оценили потенцијале геопарка. Међутим, процес евалуације за подручје Ђердап још није 
завршен због одлуке чланова Савета UNESCO Глобалне мреже геопаркова да се кандидатура предложеног геопарка одложи на највише две године како би се омогућило побољшање квалитета апликације.

Као приоритетни задаци у наредном периоду издвојени су: промоција објеката геонаслеђа у мас-медијима, успостављање и обележавање нових туристичких рута (геомаршруте), планирање и организовање нових едукативних и туристичких програма намењених различитим циљним групама, припрема акционих и финансијских планова, као и издвајање реалних финансијских средстава за имплементацију планираних активности.

Незагађена животна средина, разноврсност природних ресурса посебно геолошких, атрактивни предели, богатство биљног и животињског света, бројне културно-историјске знаменитости, љубазност и гостопримство локалних становника основне су одлике Ђердапа. За ово подручје, пријем у UNESCO Мрежу геопаркова имао би вишеструки значај: јачање свести локалног становништва о заштити природе и јачање њиховог идентитета, шансу за размену идеја, стратегија и искустава о заштити и очувању природе и природних вредности са другим геопарковима и стицање заштитног знака, који би га учинио препознатим на само у региону већ и широм Света. 